One striking innovation is the use of an unnamed symbol for tho Helmholtz free-energy. It is formed by running together $\mathrm{A}$ and $\mathrm{F}$.

J. S. ROWLINSON

\section{SOLAR SYSTEM ASTRONOMY}

Moon and Planets

Edited by A. Dollfus. (A Session of the Seventh International Space Science Symposium held in Vienna on May 10-18, 1966.) (Sponsored by COSPAR and IAU.) Pp. 321 26 photographs. (Amsterdam: North-Holland Publishing Company, 1967.) 90s.

The progress which space scienco has made during its first decade has astonished even some of its moro optimistic proponents, and it has become difficult in these days of the information explosion for astronomers pursuing their work in extra-solar-system astronomy to koop abreast of devolopments in space scionce (apart from a fow wellpublicized glamorous discoveries). And in spite of the developments which have taken place, it must be recognized that our new knowledge is fragmentary, and that new quostions are being asked faster than they can be answered. Many of us look forward to the day when it will be possible to publish an important textbook, with all its chapters fully integratod one with another, and covering the main aspects of planetary and lunar astronomy, with a full and adequate account of modern developments. Clearly, such a book, if writton now, would bo promature. We must therefore be grateful for the present volume. Its most valuable foature is undoubtedly a number of survey papers, which will bo of interest to a wider audionce than some of the individual contributions and abstracts. I single out for montion articles by G. P. Kuiper on the lunar surface and the US Ranger programme, by A. D. Kuzmin on the results of radio observations of the planets, by I. I. Shapiro on planetary radar astronomy, by $O$. W. Nicks on the Mariner IV results, by R. K. Sloan on the Mariner IV photographs of Mars, and by W. C. DeMarcus on the general theory of (the internal structure of the) planets. The volume is a required purchase for libraries of physies and astronorny because of theso surveys, and the lattor will be valuable as basic roforences for astrophysics and space scionce students until such a time as more integrated treatmont of solar system astronomy bocomes available.

\section{Iv. H. Garstang}

\section{QUANTUM THEORY OF FIELDS}

\section{Lectures on Quantum Field Theory}

By Paul A. M. Dirac. (Belfer Graduato School of Science Monograph Sories, No. 3.) Pp. viii +151. (Now York: Belfer Graduate School of Scionce, Yeshiva Univorsity, 1966. Distributed by Academic Pross, New York and London.) $60 s$.

Professor Drirac's book, as its title and colloquinl stylo suggest, is based on a lecture courso given by him in tho session 1963-64 at Yoshiva University, Now York. This is not a toxtbook in tho conventional senso: it is, rather, a critical essay in which the essayist describes lucidly his thoughts on the difficulties and illogicalities of the traditional approach to tho quantum thoory of fields; then in developing the theory of quantum electrodynamics he demonstrates just how he has come to terms with the problems ho has raised.

The underlying philosophy of the book has already received considerablo publicity ${ }^{1,2}$. Lotterss to Nature ${ }^{3,4}$ on the subject of the first article indicate that the ideas put forward aro not altogether uneontroversial.

Tho essential point which Professor Dirac makes is that, in the field thenrotic context, "the Heisenberg picture is a good picture and the Schrödinger picture is a bad picture and that the two pictures are not equiv alent". The essence of this point is made explicit when a simple field theoretic model is analysed. Thereafter the author sets about the task of developing a quantum field theory (quantum electrodynamies) working entirely within the framework of the Heisenberg picture and avoiding any diroct use of the Schrödinger picture. In any theory which does not admit Schrödinger wave functions the usual probabilistic interpretation of the theory must be abandoned. This problem is tackled by the author and a new basis of interpretation is suggested. Important in these new interpretative proposals is the normal ordering of operators and this, being deemed of physical significance, is taken over from work done in tho Schrödinger picture. By developing quantum electrodynamics in the Heisenberg picture many but not all of the "illogical" infinities of the traditional approach are snccessfully eliminated; it is proposod that other infinities bo romoved by the introduction of cut-offs, and the arguments presented here seem to me plausible rather than strictly logical. Professor Dirac is careful to point out that oach standpoint adopted is merely that which seems to him to be the best at the present stage of knowledge and that we must always be ready to alter our point of view in the light of new facts.

In this formulation there is no place for an $S$-matrix and it would have been interesting to have had Professor Dirac's evaluation of the extensive literature on $S$-matrix theory and other modern outgrowths of traditional field theory.

I am certain that Lectures on Quantum Field Theory will provide the serious student with most interesting and stimulating reading: the arguments aro presented with great clarity and the layout (despite the absence of an index, which is largely compensated for by the paragraph titles) is good. John Cunningham

'Dirac, P. A. M., Nature, 203, 115 (1964)

${ }^{2}$ Dirac, P. A. M., Phys. Rev., 139B, 685 (1965).

${ }^{3}$ Perlman, H. S., Nature, 204, 771 (1964).

'Simon, J. M., and Taylor, J. G., Nature, 205, 1305 (1965).

\section{MAN'S WORLD}

\section{The Science of Society}

An Introduction to Sociology. By Stephen Cotgrove. (The Minerva Serios of Student's Handbooks, No. 19.) Pp. 310. (London: George Allen and Unwin, Ltd., 1967.) 40s. not. Trrs is an erudite, yet readable and easily assimilated, introductory textbook of sociology. Using the structurefunction approach, in particular the "theories" and perspectivos developed by Talcott Parsons, the author marshals a judicious mixture of British and American researeh findings into a toxt which both serves as an introduction to the elements of sociological analysis and offers the reader a description of contemporary British institutions. This is somcthing of an achievement, for tho "theoretical" frame of referenco is not a simple one, and its exponents are not noted for clarity and simplicity in their prose style. The book differs from many introductory sociology textbooks by adopting the refreshing approach of assuming that its readors road other books. In particular it was pleasing to find that tho author had dispensed with the traditional obeisance to the "Founding Fathers of Sociology" and settled for a discussion of what sociology is about today.

The work of Talcott Parsons has had a great influence on modern sociological teaching and rosearch. Good textbooks using his frame of reference, however, have been rare. Those using it have made the mistake of forcing the material into the conceptual framework in the mistaken belief that it is a vorified theory. While Profossor Cotgrove closely adheres to the scheme he does not fall into 